\title{
Metallomics
}

Cite this: Metallomics, 2013 5, 514

Received 19th December 2012, Accepted 18th February 2013

DOI: $10.1039 / c 3 m t 20252 f$

www.rsc.org/metallomics

\section{A platinum complex that binds non-covalently to DNA and induces cell death via a different mechanism than cisplatin $\dagger$}

\author{
Kogularamanan Suntharalingam, ${ }^{a}$ Oscar Mendoza, ${ }^{a}$ Alexandra A. Duarte, ${ }^{b}$ \\ David J. Mann*b and Ramon Vilar*a
}

\begin{abstract}
Cisplatin and some of its derivatives have been shown to be very successful anticancer agents. Their main mode of action has been proposed to be via covalent binding to DNA. However, one of the limitations of these drugs is their poor activity against some tumours due to intrinsic or acquired resistance. Therefore, there is interest in developing complexes with different binding modes and mode of action. Herein we present a novel platinum(॥)-terpyridine complex (1) which interacts non-covalently with DNA and induces cell death via a different mechanism than cisplatin. The interaction of this complex with DNA was studied by UV/Vis spectroscopic titrations, fluorescent indicator displacement (FID) assays and circular dichroism (CD) titrations. In addition, computational docking studies were carried out with the aim of establishing the complex's binding mode. These experimental and computational studies showed the complex to have an affinity constant for DNA of $\sim 10^{4} \mathrm{M}^{-1}, \mathrm{a}$ theoretical free energy of binding of $-10.83 \mathrm{kcal} \mathrm{mol}^{-1}$ and selectivity for the minor groove of DNA. Long-term studies indicated that $\mathbf{1}$ did not covalently bind (or nick) DNA. The cancer cell antiproliferative properties of this platinum(II) complex were probed in vitro against human and murine cell lines. Encouragingly the platinum(॥) complex displayed selective toxicity for the cancerous (U2OS and SH-SY5Y) and proliferating NIH 3T3 cell lines. Further cell based studies were carried out to establish the mode of action. Cellular uptake studies demonstrated that the complex is able to penetrate the cell membrane and localize to the nucleus, implying that genomic DNA could be a cellular target. Detailed immunoblotting studies in combination with DNA-flow cytometry showed that the platinum(॥) complex induced cell death in a manner consistent with necrosis.
\end{abstract}

\section{Introduction}

Platinum complexes have received great attention as anticancer agents, ${ }^{1-6}$ largely due to the clinical success of cisplatin and its derivatives (such as oxaliplatin, nedaplatin, lobaplatin and carboplatin). ${ }^{7}$ These clinically approved platinum based agents interact with DNA by forming intra- and inter-stranded crosslinks (covalent Pt-DNA bonds). ${ }^{8-13}$ These modifications structurally kink DNA and inhibit transcription (by stalling polymerase), resulting in controlled cell death. ${ }^{11,14,15}$ The main limitation of these drugs is their poor activity against some

\footnotetext{
${ }^{a}$ Department of Chemistry, Imperial College London, London SW7 2AZ, UK. E-mail: r.vilar@imperial.ac.uk

${ }^{b}$ Division of Molecular Biosciences, Imperial College London, London SW7 2AZ, UK. E-mail: d.mann@imperial.ac.uk

† Electronic supplementary information (ESI) available. See DOI: 10.1039/ c3mt20252f
}

tumors due to intrinsic or acquired resistance. ${ }^{16,17}$ Therefore new platinum drugs are needed that build on the mechanisms associated to clinically approved platinum drugs but bypass their inherent resistance.

As an alternative, many platinum complexes bearing $\pi$-conjugated heterocyclic ligands have been developed and their anti-cancer properties investigated. ${ }^{18-21}$ The planar aromatic ligand allows these complexes to intercalate between base pairs. The first structural evidence of this binding mode was reported almost 40 years ago by Lippard et $a .^{22}$ In this seminal paper, a platinum(II)-terpyridine complex was shown to intercalate noncovalently between adjacent DNA base pairs, resulting in the unwinding of the DNA. Similar complexes with leaving groups were shown to bind covalently, favourably targeting the N7 position on guanosine bases (like cisplatin). ${ }^{23-28}$ In recent years, vast libraries of platinum(II)-terpyridine compounds have been prepared (with modifications to the terpyridine ligand and 
various groups attached to the platinum center) and tested as potential anti-cancer agents. ${ }^{29}$ Many of these complexes have shown great promise; for example a report by McFadyen and co-workers showed a series of platinum(II)-terpyridine complexes with electron rich/deficient thiol ligands (attached directly to platinum) to be active against the L1210 murine leukemia cell line. ${ }^{30}$ Interestingly, a follow up study found the parent $[\mathrm{Pt}(\text { terpy }) \mathrm{Cl}]^{+}$species, with a labile chloro substituent to be relatively ineffective $\left(\mathrm{IC}_{50}=450 \mu \mathrm{M}\right)$, implying that platination is not a determinant of cytotoxicity. ${ }^{31}$ Other variations to groups attached to platinum (using picoline, thioalkylcarboranes, glycosylated acetylides) have resulted in higher water solubility and potency against cisplatin- and doxorubicinresistant cell lines (human ovarian carcinoma). ${ }^{31-37}$

The majority of platinum(II)-terpyridine systems that have been reported to date (and shown anti-cancer activity), bind to DNA via intercalation or coordination. However some platinum(II)-terpyridines can bind via other non-intercalative modes. Indeed platinum(II)-terpyridine thiol and acetylide compounds have been shown to bind via electrostatic and hydrophobic interactions. ${ }^{38}$ Furthermore, the addition of sterically demanding groups such as $t$-butyl on the terpyridine ligand has yielded highly active anti-cancer agents that interact with the DNA grooves. ${ }^{34}$ When designing potential anti-cancer agents, non-intercalative platinum(II)-terpyridine complexes are largely overlooked in favor of metallo-intercalators. Given the success of groove binders such as Tallimustine ${ }^{39,40}$ and Brostallicin ${ }^{41,42}$ (both have undergone clinical trials) in cancer therapy, it is surprising that very few groove binding platinum(II)-terpyridine complexes have been reported. With the aim of exploring the ability of new metal complexes as DNA groove binders, we have prepared a platinum(II)-terpyridine complex (1) bearing two piperidine substituents at positions 2 and $2^{\prime}$ (see Scheme 1). The substituents were placed in these positions with the aim of hindering direct coordination to the platinum(II) centre and to potentially favour groove and phosphate binding (aided by the piperidine groups which at physiological $\mathrm{pH}$ are protonated). Besides its synthesis and full characterization, herein we also report the DNA binding properties of $\mathbf{1}$ (including docking studies to rationalize the interactions) as well as its behaviour in cells. We have carried out a series of experiments aimed at dissecting its cytotoxic mechanism of action.

\section{Results and discussion}

\section{Synthesis and characterization}

The new terpyridine ligand was prepared by reacting $6,6^{\prime \prime}$-dibromo-2,2': $6^{\prime} 2^{\prime \prime}$-terpyridine with two equivalents of 1-(2-hydroxyethyl)piperidine in DMSO under strong basic conditions (powdered $\mathrm{KOH}$ ) at $85{ }^{\circ} \mathrm{C}$ for $24 \mathrm{~h}$ (see Scheme 1). The product was extracted into dichloromethane, washed several times with water and isolated after solvent removal. The resultant off-white solid was fully characterized by ${ }^{1} \mathrm{H}$ and ${ }^{13} \mathrm{C}$ NMR spectroscopy, mass spectrometry and elemental analysis. The attachment of the side arms was clearly illustrated by the downfield shift of the carbon signal corresponding to the

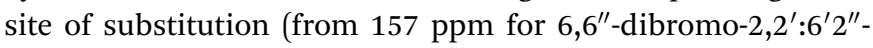
terpyridine to $163 \mathrm{ppm}$ for $\left.\mathbf{L}^{\mathbf{1}}\right)$. The $\operatorname{ESI}(+)$ mass spectrum showed a signal corresponding to the expected molecular ion, confirming the formation of the desired product.

The new platinum(II)-terpyridine complex 1 was prepared by stirring $\mathbf{L}^{1}$ with $\mathrm{K}_{2} \mathrm{PtCl}_{4}$ in DMSO overnight. The product was isolated pure as the $\mathrm{PF}_{6}{ }^{-}$salt after anion exchange. The platinum(II)terpyridine complex 1 was fully characterized by ${ }^{1} \mathrm{H}$ NMR spectroscopy (which showed characteristic shifts of some of the aromatic signals upon coordination to platinum), UV/Vis spectroscopy, ESI $(+)$ mass spectrometry and elemental analysis.

Before studying the interaction between 1 and DNA, the stability of the complex was investigated using UV-Vis and ${ }^{1} \mathrm{H}$ NMR spectroscopies. The absorption spectrum for $\mathbf{1}(50 \mu \mathrm{M}$ in Tris- $\mathrm{HCl} 10 \mathrm{mM} / \mathrm{KCl} 100 \mathrm{mM}$ with and without cell lysate, 3.4 mg of protein) was recorded over $24 \mathrm{~h}$ (see Fig. S3 and S4, ESI $\dagger$ ). The MLCT band was examined for any signs of platinum dissociation/reactivity. Over this period of time no significant changes were detected. Therefore the complex was deemed to be stable under the conditions used for the DNA binding and cellular assays. To probe the thermal stability of 1 , its ${ }^{1} \mathrm{H}$ NMR spectrum (80 mM in DMSO- $\mathrm{d}_{6}$ ) was recorded between $25-110{ }^{\circ} \mathrm{C}$ (see Fig. S2, ESI $\dagger$ ). Over this temperature range the complex was found to be stable (displaying the expected chemical shifts and splitting patterns throughout).

\section{DNA binding studies}

UV-Vis spectroscopic titrations were carried out to determine the binding affinity and binding mode of 1 to DNA. Upon addition of aliquots of Calf Thymus DNA (ct-DNA), in the mM range, to a solution of 1 of known concentration $(20 \mu \mathrm{M})$, the absorption band corresponding to the metal perturbed intra-ligand $\pi \rightarrow \pi^{*}$ transition (300-320 nm) was observed to decrease (see Fig. S5, ESI $\dagger$ ). From the absorbance, the concentration of bound and unbound metal complex was calculated and extrapolated to determine the binding constant. This was done by fitting the data to a reciprocal plot of $D / \Delta \varepsilon_{\text {ap }}$ versus $D$ using the following equation: $D / \Delta \varepsilon_{\text {ap }}=D / \Delta \varepsilon+1 /(\Delta \varepsilon \times K)$, details

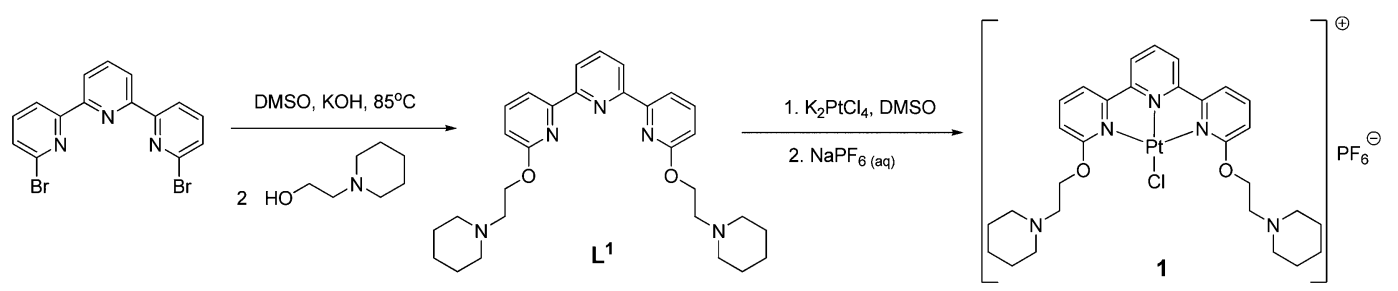

Scheme 1 The synthetic procedure used to prepare the platinum(॥)-terpyridine complex used in this study. 
are provided in the Experimental section. The intrinsic binding affinity was found to be $6.10 \pm 0.94 \times 10^{4} \mathrm{M}^{-1}$. Notably this value is 1 to 2 orders of magnitude lower than those reported for platinum(II)-terpyridine intercalators, suggesting a nonintercalative binding interaction between 1 and ct-DNA. ${ }^{43-45}$

The addition of ct-DNA to 1 resulted in hypochromicity (14\%), no red shifts and sharp isosbestic points. These features are characteristic of compounds that interact with DNA via groove binding. ${ }^{46,47}$ The complex can be envisaged to engage bases in the grooves by $\pi-\pi$ interactions (through the planar terpyridine moiety) and, at the same time, form hydrogen bonding and/or electrostatic interactions with the negatively charged phosphate backbone (via the piperidine side arms).

In order to investigate the binding mode further, fluorescent indicator displacement (FID) studies were carried out with two different dyes: a DNA intercalator, thiazole orange (TO) and a DNA minor groove binder, Hoechst $33258 .{ }^{48-51}$ Comparison of the $\mathrm{DC}_{50}$ values (the concentration required to displace $50 \%$ of the respective dyes from duplex DNA) obtained from the different dyes gives an insight into the binding mode (see Table S1 and Fig. S6, ESI $\dagger$ ). The results clearly showed that Hoechst was preferentially displaced over TO (over 3-fold selectivity). Therefore $\mathbf{1}$ can be proposed to preferentially bind via the DNA grooves.

To gain further insight into the binding mode between this complex and DNA, circular dichroism studies were carried out. CD spectra of ct-DNA treated with 1 ( 1 : DNA ratio of 0.5 or 1 ) showed no change in profile relative to the untreated control (only changes in the intensities of the bands related to helicity and base stacking; see Fig. S7, ESI $\dagger$ ). These spectral changes are comparable to those reported for other metal containing groove binders. ${ }^{52-54}$

Computational docking studies were carried out to gain theoretical insight into the interaction between 1 and DNA. Thus the optimised structure of the metal complex (see ESI $\dagger$ for further details) was docked with a B-DNA structure (taken from the protein data bank; 1BNA) using Autodock. ${ }^{55}$ The docked model suggests that 1 interacts with the minor groove of DNA (see Fig. 1). The almost planar structure of the complex fits into the minor groove of the DNA in a parallel manner with respect to the DNA backbone. The two alkane chains of the complex remain out of the groove, pointing to DNA's backbone.
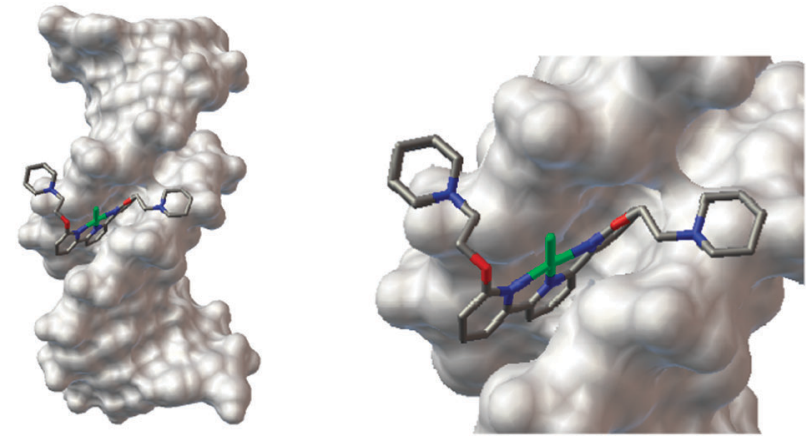

Fig. 1 (a) Computational docking model (using the Autodock software) illustrating the interaction between 1 and B-DNA (PDB ID:1BNA). (b) Magnified view of the interaction between 1 and DNA.

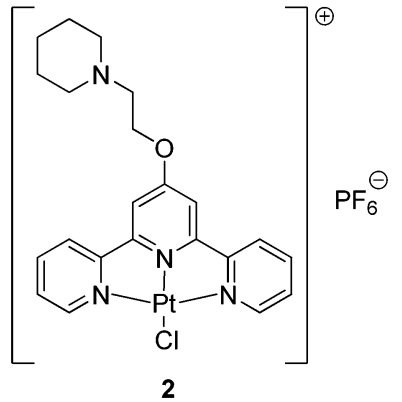

Fig. 2 Platinum(॥) complex used as positive control in the selective precipitation of ct-DNA method. This complex has been previously shown to interact with ct-DNA via direct coordination.

The positively charged piperidines and the negatively charged phosphate groups from the backbone are linked by a hydrogen bond $(2.10 \AA)$. The estimated free energy of this binding was computed to be $-10.83 \mathrm{kcal} \mathrm{mol}^{-1}$. Therefore the UV-Vis, FID, $\mathrm{CD}$ and computational docking data collectively suggest that $\mathbf{1}$ is a DNA groove binder.

The bio-physical studies described thus far were all carried out within an incubation time of complex 1 and DNA of $2 \mathrm{~h}$. Therefore further studies were carried out to determine whether the complex was able to coordinate to DNA over a longer period of time. Coordination was probed spectrophotometrically using the established selective precipitation of ct-DNA method which detected covalent binding of a given compound to DNA. ${ }^{56-58}$ A solution of ct-DNA was incubated with 1 at a bp : metal complex ratio of $5: 1$ at $37^{\circ} \mathrm{C}$; in a separate solution complex 2 (see Fig. 2) ${ }^{59}$ was incubated with DNA (bp:metal complex ratio of $5: 1$ and $37{ }^{\circ} \mathrm{C}$ ) and used as a positive control (i.e. $\mathbf{2}$ is able to platinate DNA).

At specific time intervals, aliquots were taken from these solutions and the DNA within the sample precipitated. The amount of unbound metal complex was determined using UV-Vis spectroscopy. The change in the absorbance of the supernatant was then plotted against time to determine the covalent binding ability. The amount of $\mathbf{1}$ in the supernatant remained constant throughout (while this was seen to decrease for the positive control, i.e. compound 2), suggesting that 1 was unable to bind covalently to DNA (see Fig. S8, ESI $\dagger$ ). Agarose gel electrophoresis studies with supercoiled pUC19 plasmid DNA treated with different concentrations of 1 (at $37^{\circ} \mathrm{C}$ for $24 \mathrm{~h}$ ) also gave no detectable coordination (or nicking) to DNA (see Fig. S9, ESI $\dagger$ ). The ability of complex 1 to coordinate to DNA bases was further probed by ${ }^{1} \mathrm{H}$ NMR spectroscopic studies. Incubating 1 with guanosine over a $24 \mathrm{~h}$ produced no changes to the ${ }^{1} \mathrm{H}$ NMR spectrum (see Fig. S10, ESI + ), indicating that the platinum(II) does not coordinate to guanosine. Overall, the bio-physical and computational data are consistent with 1 binding to the minor groove of DNA in a non-covalent manner.

\section{Cellular studies}

The anti-proliferative properties of 1 were assessed using the MTS assay (using the CellTiter $96^{\circledR}$ AQueous Assay from Promega). 
Table 1 IC 50 values obtained for 1 against U2OS, HEK 293T, GM05757 and SHSY5Y cell lines after a $24 \mathrm{~h}$ incubation period. The values are an average of three independent measurements. The $\mathrm{IC}_{50}$ values obtained for cisplatin were previously reported ${ }^{60}$

\begin{tabular}{|c|c|c|c|c|}
\hline Compound & $\mathrm{U} 2 \mathrm{OS}(\mu \mathrm{M})$ & HEK 293T $(\mu \mathrm{M})$ & GM05757 $(\mu \mathrm{M})$ & SH-SY5Y $(\mu \mathrm{M})$ \\
\hline 1 & $33 \pm 4$ & $68 \pm 8$ & $130 \pm 12$ & $52 \pm 4$ \\
\hline Cisplatin & $48 \pm 6$ & $109 \pm 12$ & $74 \pm 6$ & $54 \pm 4$ \\
\hline
\end{tabular}

Data for cisplatin under the same conditions are also reported for comparison. Four cell lines were initially tested: U2OS (human osteosarcoma), HEK 293T (human embryonic kidney), GM05757 (normal human fibroblast) and SH-SY5Y (neuroblastoma). The $\mathrm{IC}_{50}$ values were derived from dose-response curves and are summarised in Table 1. It should be noted that the $\mathrm{IC}_{50}$ values reported in Table 1 are for a $24 \mathrm{~h}$ incubation period - and therefore they might seem relatively high as compared to values previously reported for cisplatin for longer incubation times. Complex 1 was found to have a promising toxicity profile, with high potency toward the cancerous U2OS and SH-SY5Y cell lines (comparable to cisplatin in this $24 \mathrm{~h}$ incubation period) and reduced toxicity toward the normal GM05757 cell line (4-fold difference between the U2OS and GM05757 cell lines).

Further toxicity studies with proliferating and non-proliferating NIH 3T3 mouse fibroblast cells (see Fig. S12 and S13, ESI, $\dagger$ for flow cytometry profile of the cells) showed that the complex was able to selectively induce cell death in proliferating but not quiescent cells (see Table 2). This is undoubtedly an attractive characteristic in terms of cancer therapy.

In order to rationalise the varying degrees of toxicities across the different cell lines and to relate the results to genomic DNA interactions, further cell based studies were undertaken. Cellular uptake studies were performed to determine cell permeability and localization of 1 . To do this, U2OS, HEK 293T, GM05757, SH-SY5Y and NIH 3T3 (for the latter, both proliferating and quiescent) cells were incubated for $24 \mathrm{~h}$ at $37{ }^{\circ} \mathrm{C}$ with a sub-lethal concentration $(10 \mu \mathrm{M})$ of 1 and the platinum content determined for whole cell, nucleus and cytoplasm fractions using Inductively Coupled Plasma Mass Spectrometry (ICP-MS). Cellular platinum levels are expressed as ng platinum per $\mathrm{mg}$ protein and the results reported as a mean of four or five determinations for each data point (summarised in Fig. 3).

These studies showed that complex $\mathbf{1}$ was taken up well by all of the cell lines, except NIH 3T3 under non-proliferating conditions. The inability of $\mathbf{1}$ to penetrate the latter type of cell under starved conditions explains its lack of toxicity $\left(\mathrm{IC}_{50}>500 \mu \mathrm{M}\right)$ under these conditions. The highest cellular uptake was observed for the cancerous U2OS and SH-SY5Y cell lines $(15-18 \%$ of the

Table $2 \quad I C_{50}$ values obtained for 1 against the NIH 3 T3 cell line under proliferating and non-proliferating conditions. The values are an average of three independent measurements

\begin{tabular}{lcl}
\hline Compound & Proliferating NIH 3T3 $(\mu \mathrm{M})$ & Quiescent NIH 3T3 $(\mu \mathrm{M})$ \\
\hline $\mathbf{1}$ & $60 \pm 12$ & $>500$ \\
Cisplatin & $145 \pm 13$ & $>500$
\end{tabular}

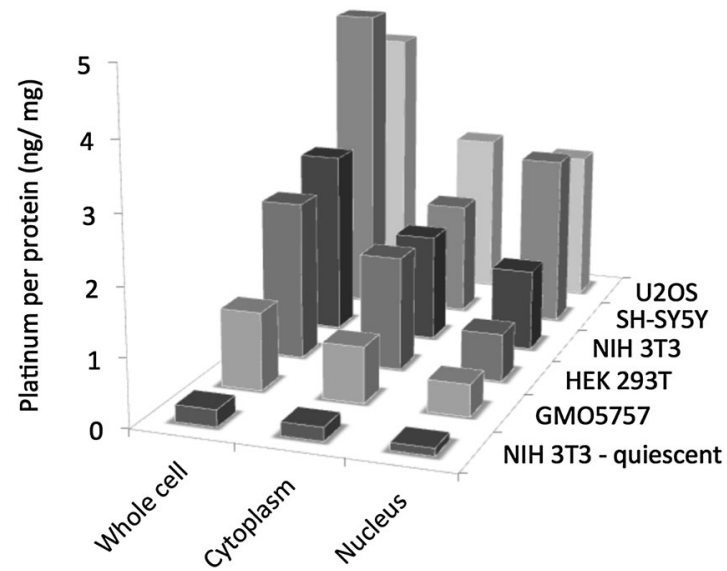

Fig. 3 Cellular uptake data for 1. The amount of platinum (ng) per protein (mg) is expressed for the whole cell, cytoplasm and nucleus. The exact Pt/protein values and the corresponding errors are reported in Table S2 (ESIt).

administered complex at $10 \mu \mathrm{M}$ enters the cell) and lowest for the normal human GM05757 cell line (in terms of the whole cell, the platinum content was found to be around 5-fold lower in this case). These variations in uptake may explain the differences in toxicities reported for the respective cell lines. Importantly, in all cases, $\mathbf{1}$ was found to enter the nucleus, giving access to genomic DNA. Therefore cellular toxicity could result from mechanisms related to genomic DNA damage. However it should be noted that a significant portion of the complex was also found in the cytoplasm, this could be due to off target interactions with traditional Pt-drug scavengers found in the cytoplasm ${ }^{61}$ like metallothionein or glutathione.

To establish whether $\mathbf{1}$ was able to induce DNA damage, immunoblotting analysis was carried out to monitor changes in the expression levels of biomarkers of the DNA damage response pathway (the phosphorylated forms of histone $\mathrm{H} 2 \mathrm{AX}$ $(\gamma \mathrm{H} 2 \mathrm{AX})$ and Chk2 protein kinase, both of which increase due to activation of the apical kinases ATM and ATR). ${ }^{62-66}$ Therefore U2OS cells were treated with $1(10-60 \mu \mathrm{M})$ for $24 \mathrm{~h}$ at $37^{\circ} \mathrm{C}$ and collected for immunoblotting analysis (see Fig. 4). After treatment with $60 \mu \mathrm{M}$ of 1 , a visible increase in $\gamma \mathrm{H} 2 \mathrm{AX}$ and phosphorylated Chk2 (with total Chk2 remaining constant) was observed (see Fig. 4). Therefore the increase in $\gamma \mathrm{H} 2 \mathrm{AX}$ and phosphorylated Chk2 expression indicates that $\mathbf{1}$ was able to induce DNA damage in cells. DNA damage can lead to a wide range of cellular responses; the p53 protein (which regulates cell cycle progression and induces apoptosis) ${ }^{67,68}$ plays a fundamental role in coordinating cellular response to DNA damage. ${ }^{69-71}$ Therefore it was of interest to monitor the expression of p53 and its downstream effector, p21, upon treatment with 1. Addition of 1 resulted in a dose dependent increase in p53 and p21 levels, suggesting that these downstream regulators play a part in the cellular response. In addition, treatment with $60 \mu \mathrm{M}$ of 1 led to loss of cyclin D1, a pro-proliferative cyclin involved in G1 phase progression. $^{72-74}$ Loss of cyclin D1 is another characteristic response to DNA damage. ${ }^{75-78}$

To assess the effects of $\mathbf{1}$ on cell cycle distribution we performed DNA-flow cytometric studies. U2OS cells were treated with $\mathbf{1}(10 \mu \mathrm{M})$ 


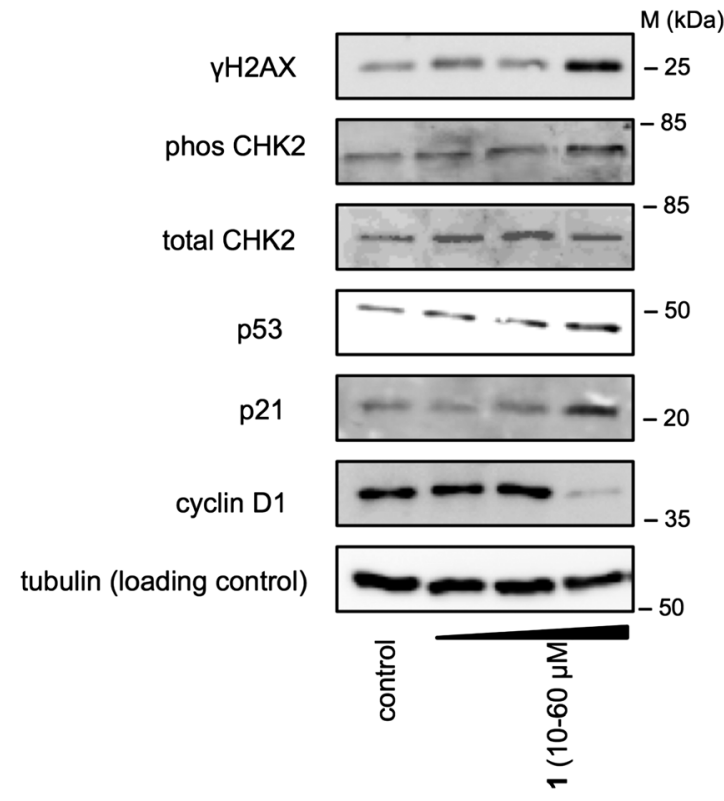

Fig. 4 Analysis of protein expression in U2OS cells following treatment with 1 $(10-60 \mu \mathrm{M})$ after $24 \mathrm{~h}$ incubation. Whole cell lysates were resolved by SDS-PAGE and analyzed by immunoblotting against $\gamma \mathrm{H} 2 \mathrm{AX}$, phosCHK2, CHK2, p53, p21, cyclin D1, and $\alpha$-tubulin (loading control). Results are representative of three independent experiments. MW = Protein Molecular Weight Marker. The relative ratios of the band intensities normalised against the loading control are reported in Fig. S15 (ESIt).

for $24 \mathrm{~h}$ and then their cell cycle distribution compared to untreated cells (see Fig. 5). Upon addition of 1, cells were observed to undergo G1 phase arrest $(+18.3 \pm 1.5 \%$ increase in $\mathrm{G} 1$ relative to the untreated cells).

Having established that $\mathbf{1}$ is able to damage DNA and induce G1 arrest, the mechanism of cell death was investigated. The most thoroughly studied and well-understood mechanism is apoptosis, ${ }^{79,80}$ and indeed many DNA damaging agents are known to exert their cytotoxic effects via this pathway. ${ }^{81-84}$ Cells that have undergone apoptosis express phosphatidylserine residues on the cell surface, which can be detected by annexin V. Thus, the annexin V-propidium iodide (PI) dual staining flow

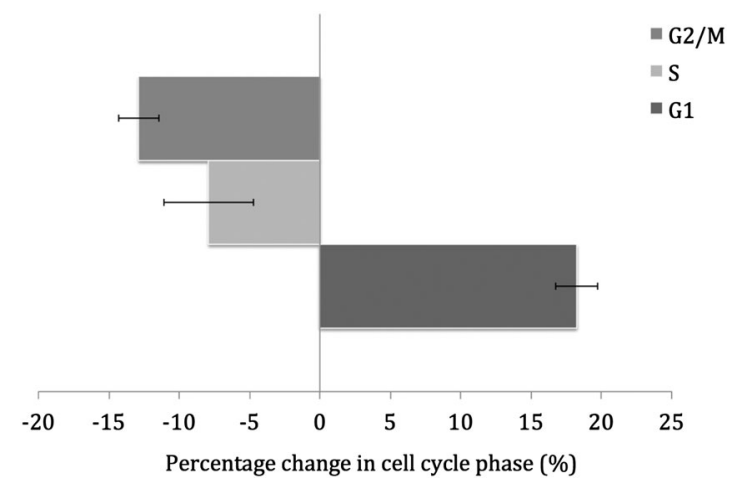

Fig. 5 Graphical representation of the percentage change in phases of the cell cycle upon treatment of U2OS cells with $1(10 \mu \mathrm{M})$. The values are an average of three independent measurements and the associated error for each value is represented in the form of capped error bars. cytometric assay (see Section S11 in the ESI $\nmid$ for further details) was used to probe apoptosis. This assay found negligible levels of early or delayed apoptosis in U2OS cells treated with $1(+3.0 \pm 1.1 \%$ and $+3.0 \pm 1.7 \%$ increase in early and late apoptosis respectively, relative to the untreated cells). Further immunoblotting analysis found that cells treated with 1 displayed no change in BAX expression (a well-known pro-apoptotic protein) and non-proteolytic cleavage of pro-caspase-3 (see Fig. S16, ESI $\dagger$ ). The addition of an apoptosis inducer, staurosporine, resulted in BAX up-regulation and pro-caspase-3 breakdown (see Fig. S17, ESI $\dagger$ ). Therefore the data suggest that cell death invoked by 1 occurs in a non-apoptotic manner.

After ruling out apoptosis, other modes of cell death were investigated. To this aim cytotoxicity assays were conducted in the presence of necrosis and autophagocytosis inhibitors (necrostatin-1 and 3-aminobenzamide for necrosis and chloroquine for autophagocytosis). U2OS cells were treated with the inhibitors using conditions previously reported $^{85}$ and the results are summarised in Fig. 6. Chloroquine had little effect on toxicity exhibited by $\mathbf{1}$, hence autophagocytosis is unlikely. 3-Aminobenzamide and necrostatin-1 had more profound effects on cell death induced by 1 (2-fold and 4 -fold increase in $\mathrm{IC}_{50}$ value compared to the untreated control). Therefore cell death induced by $\mathbf{1}$ is likely to result from necrosis/necroptosis.

Cells that have undergone necrosis are known to passively release HMGB1 $^{86}$ (a chromatin component essential for cell survival ${ }^{87}$ ). Remarkably, in apoptotic cells, HMGB1 remains tightly bound to the chromatin, therefore the presence of extracellular HMGB1 serves as a marker for necrosis. ${ }^{88}$ U2OS cells were treated with toxic concentrations of $1(50-200 \mu \mathrm{M})$ for $48 \mathrm{~h}$ and the extracellular media were probed for HMGB1 (see Methods section for detailed description). After treatment with $200 \mu \mathrm{M}$ of $1, \mathrm{HMGB} 1$ was clearly detected in the extracellular media, indicative of necrosis (see Fig. S17, ESI $\dagger$ ). This was comparable to HMGB1 released from necrotic cells (induced by heating to $56{ }^{\circ} \mathrm{C}$ for $30 \mathrm{~min}$ ). Therefore the cytotoxicity profiles in the presence of different inhibitors and the HMGB1 secretion data suggest that $\mathbf{1}$ induces necrotic cell death.

Necrosis has conventionally been overlooked as a mode of cell death for anti-cancer therapy. However it is now widely

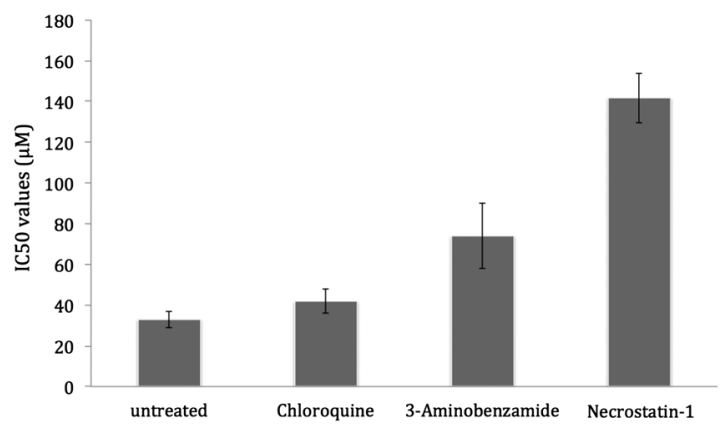

Fig. $6 I C_{50}$ values obtained for 1 against the U2OS cell line in the absence and presence of necrosis and autophagocytosis inhibitors; necrostatin-1 (60 $\mu \mathrm{M}, 1 \mathrm{~h}$ ), 3-aminobenzamide ( $2 \mathrm{mM}, 1 \mathrm{~h})$ and chloroquine $(10 \mu \mathrm{M}, 6 \mathrm{~h})$. The values are an average of five independent measurements and the associated error for each value is represented in the form of capped error bars. 
regarded as an "ancestral mode of programmed cell death" by many researchers in the cell death research community. ${ }^{89}$ The discovery of 432 genes $^{90}$ and various proteins (in viruses) ${ }^{91}$ associated to the induction of necrosis has proved that it is in fact a highly regulated process. ${ }^{92-94}$ Necrosis results in the secretion of cytokines; therefore selective induction of necrosis in tumour cells can activate the immune system against tumours and improve the efficacy of anti-cancer agents. ${ }^{95}$ As DNA damage is known to trigger necrosis, we believe that 1 acts in a controlled manner, where it induces genomic DNA damage which ultimately leads to necrosis.

\section{Conclusions}

In summary, we report the DNA binding properties of a novel platinum(II) complex (1). The complex was found to interact with duplex DNA (with affinity in the order of $10^{4} \mathrm{M}^{-1}$ ) and bind to the minor groove of DNA (theoretical free energy of binding was $-10.83 \mathrm{kcal} \mathrm{mol}^{-1}$ ). Longer term studies were used to demonstrate that DNA binding was not covalent. Cellular uptake studies demonstrated that the platinum complex was found to enter the nucleus, giving it access to genomic DNA. Complex 1 evoked a DNA damage response, giving rise to the accumulation of $\gamma \mathrm{H} 2 \mathrm{AX}$, phosphorylated CHK2 and activation of p53, indicative of DNA damage. Compound 1 was found to have a promising cytotoxicity profile, displaying selective toxicity for cancerous cell lines (U2OS; $\mathrm{IC}_{50}=33 \mu \mathrm{M}$ and SH-SY5Y; $\mathrm{IC}_{50}=52 \mu \mathrm{M}$ ) over the normal fibroblast cell line $\left(\right.$ GM05757; $\left.\mathrm{IC}_{50}=130 \mu \mathrm{M}\right)$. The complex also showed selective potency for proliferating compared to quiescent NIH 3T3 cells. These characteristics are appealing in terms of anti-cancer therapy. Prolonged treatment with 1 led to cell death, which could be largely blocked by co-treatment with necrosis/ necroptosis inhibitors. Taken together, our data indicate that groove binding platinum(II)-terpyridine complexes may be worth exploring as novel anti-cancer agents.

\section{Experimental details}

\section{Synthesis of $\mathbf{L}^{\mathbf{1}}$}

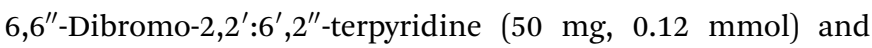
1-(2-hydroxyethyl)piperidine $(73 \mathrm{mg}, 0.28 \mathrm{mmol})$ were slowly added to a stirred suspension of powdered $\mathrm{KOH}(36 \mathrm{mg}$, $0.64 \mathrm{mmol}$ ) in DMSO $(5 \mathrm{~mL})$. The solution was stirred under a nitrogen atmosphere at $60{ }^{\circ} \mathrm{C}$ for $24 \mathrm{~h}$. The reaction mixture was extracted with DCM $(50 \mathrm{~mL} \times 3)$, washed thoroughly with water $(30 \mathrm{~mL} \times 3)$ and dried over sodium sulphate. The solvent was removed under reduced pressure to yield the product as a brown solid (32 mg, 52\%); ${ }^{1} \mathrm{H}$ NMR (400 $\mathrm{MHz}, \mathrm{CDCl}_{3}$ ): $\delta_{\mathrm{H}} 8.41$ $\left(\mathrm{d}, 2 \mathrm{H},{ }^{3} J_{\mathrm{HH}}=8.0, \mathrm{tpy}^{\prime} 3-\mathrm{H}\right.$ and $\left.5-\mathrm{H}\right), 8.45\left(\mathrm{~d}, 2 \mathrm{H},{ }^{3} J_{\mathrm{HH}}=8.0\right.$, tpy $5-\mathrm{H}), 7.93\left(\mathrm{t}, 1 \mathrm{H},{ }^{3} J_{\mathrm{HH}}=8.0, \mathrm{tpy}^{\prime} 4-\mathrm{H}\right), 7.76\left(\mathrm{t}, 2 \mathrm{H},{ }^{3} J_{\mathrm{HH}}=8.0\right.$, tpy $4-\mathrm{H}), 6.83\left(\mathrm{~d}, 2 \mathrm{H},{ }^{3} J_{\mathrm{HH}}=8.0\right.$, tpy $\left.3-\mathrm{H}\right), 4.69\left(\mathrm{t}, 4 \mathrm{H},{ }^{3} J_{\mathrm{HH}}=6.0\right.$, ethyl 1-H), $2.95\left(\mathrm{t}, 4 \mathrm{H},{ }^{3} \mathrm{~J}_{\mathrm{HH}}=6.0\right.$, ethyl $\left.2-\mathrm{H}\right), 2.67(\mathrm{~m}, 8 \mathrm{H}$, pip 1-H), 1.72 (m, 8H, pip 2-H), 1.53 (m, 4H, pip 3-H); ${ }^{13} \mathrm{C}$ NMR $\left(400 \mathrm{MHz} \mathrm{CDCl}_{3}\right): \delta_{\mathrm{C}} 163.1,155.2,153.6,139.3,137.5,120.7$, 113.8, 111.4, 63.3, 57.9, 55.1, 25.9, 24.2; ESI-MS calcd for
$\mathrm{C}_{29} \mathrm{H}_{37} \mathrm{~N}_{5} \mathrm{O}[\mathrm{M}]^{+}: 487.3$ a.m.u.; found $[\mathrm{M}+\mathrm{H}]^{+}: 488.0$ a.m.u.; anal. calcd for $\mathrm{C}_{29} \mathrm{H}_{37} \mathrm{~N}_{5} \mathrm{O} 1.5 \cdot \mathrm{HCl}$ : $\mathrm{C} 64.91, \mathrm{H} 7.57, \mathrm{~N} \mathrm{12.74}$; found: $\mathrm{C}$ 64.23, H 7.13, N 12.97\%.

\section{Synthesis of $[\mathrm{Pt}(\mathrm{L1}) \mathrm{Cl}]\left(\mathrm{PF}_{6}\right),(1)$}

$\mathrm{K}_{2} \mathrm{PtCl}_{4}(0.23 \mathrm{mg}, 0.055 \mathrm{mmol})$ was added to DMSO $(3 \mathrm{~mL})$ at $50{ }^{\circ} \mathrm{C}$. To this, a solution of $\mathbf{L}^{1}(0.24 \mathrm{mg}, 0.05 \mathrm{mmol})$ in DMSO ( $3 \mathrm{~mL}$ ) was added dropwise and the resulting mixture was stirred for $15 \mathrm{~h}$ to yield a deep orange solution. The solution was then added dropwise to acetone (ca. $100 \mathrm{~mL}$ ) and a yellow solid precipitated. The product was isolated by filtration and repeatedly washed with acetone. This solid was dissolved in the minimum amount of DMSO, to which an excess of $\mathrm{NaPF}_{6}$ (as an aqueous solution) was added dropwise. The resultant yellow precipitate was isolated by filtration and washed repeatedly with water, methanol and diethyl ether. The yellow solid was dried under reduced pressure to yield the platinum complex (23 mg, 55\%); ${ }^{1} \mathrm{H}$ NMR (400 MHz, DMSO-d $\left.{ }_{6}\right): \delta_{\mathrm{H}} 8.43(\mathrm{~d}, 2 \mathrm{H}$, ${ }^{3} J_{\mathrm{HH}}=8.0$, tpy' $3-\mathrm{H}$ and $\left.5-\mathrm{H}\right), 8.28\left(\mathrm{~d}, 2 \mathrm{H},{ }^{3} J_{\mathrm{HH}}=8.0\right.$, tpy $\left.5-\mathrm{H}\right)$, $8.14\left(\mathrm{t}, 1 \mathrm{H},{ }^{3} J_{\mathrm{HH}}=8.0, \mathrm{tpy}^{\prime} 4-\mathrm{H}\right), 7.99\left(\mathrm{t}, 2 \mathrm{H},{ }^{3} J_{\mathrm{HH}}=8.0\right.$, tpy $\left.4-\mathrm{H}\right)$, $7.02\left(\mathrm{~d}, 2 \mathrm{H},{ }^{3} J_{\mathrm{HH}}=8.0\right.$, tpy $\left.3-\mathrm{H}\right), 4.81\left(\mathrm{t}, 4 \mathrm{H},{ }^{3} J_{\mathrm{HH}}=4.0\right.$, ethyl $\left.1-\mathrm{H}\right)$, $3.60\left(\mathrm{t}, 4 \mathrm{H},{ }^{3} J_{\mathrm{HH}}=6.0\right.$, ethyl 2- $\left.\mathrm{H}\right), 1.86(\mathrm{~m}, 8 \mathrm{H}$, pip $1-\mathrm{H}), 1.71(\mathrm{~m}$, 8H, pip 2-H), 1.42 (m, 4H, pip 3-H); ${ }^{31} \mathrm{P}$ NMR (400 MHz, DMSO-d 6 ): $\delta_{\mathrm{P}}-144.21$ (sept, $1 \mathrm{P},{ }^{1} J_{\mathrm{PF}}=1756, \mathrm{PF}_{6}$ ); ESI-MS calcd for $\mathrm{C}_{29} \mathrm{H}_{37} \mathrm{ClF}_{6} \mathrm{~N}_{5} \mathrm{O}_{2} \mathrm{PPt}[\mathrm{M}]^{+}: 862.2$ a.m.u.; found $\left[\mathrm{M}-\mathrm{PF}_{6}+\mathrm{K}+\mathrm{Na}\right]^{+}$: 780.0 a.m.u.; anal. calcd for $\mathrm{C}_{29} \mathrm{H}_{37} \mathrm{ClF}_{6} \mathrm{~N}_{6} \mathrm{O}_{2} \mathrm{PPt}$.1.3DMSO: C 39.94, H 4.75, N 7.37; found: C 40.34, H 4.32, N 7.00\%.

\section{Synthesis of 2}

This compound was prepared as reported previously. ${ }^{22}$

\section{Determination of DNA affinity by UV-Vis titration}

The UV-Vis spectra were recorded on a Perkin Elmer Lambda 25 spectrometer. In order to determine the binding constants of complex 1 with ct-DNA, the complex $(20 \mu \mathrm{M})$ was titrated with a concentrated solution of ct-DNA $(2.78 \mathrm{mM})$ in $50 \mathrm{mM}$ Tris- $\mathrm{HCl}$ (pH 7.4)/100 mM KCl buffer. A $1 \mathrm{~cm}$ path-length quartz cuvette was used to carry out the measurements. The binding constants were obtained by fitting the data to a reciprocal plot of $D / \Delta \varepsilon_{\text {ap }}$ versus $D$ using the following equation: $D / \Delta \varepsilon_{\mathrm{ap}}=D / \Delta \varepsilon+1 /(\Delta \varepsilon \times K)$, where the concentration of DNA is expressed in terms of base pairs (determined by measuring the absorption at $260 \mathrm{~nm}$ and the appropriate extinction coefficients), the apparent molar extinction coefficient $\varepsilon_{\mathrm{a}}=A_{\text {observed }} /[$ complex $], \Delta \varepsilon_{\mathrm{ap}}=\left[\varepsilon_{\mathrm{a}}-\varepsilon_{\mathrm{f}}\right]$ and $\Delta \varepsilon=\left[\varepsilon_{\mathrm{b}}-\varepsilon_{\mathrm{f}}\right]$. $\varepsilon_{\mathrm{b}}$ is the extinction coefficient of the DNA bound complex and $\varepsilon_{\mathrm{f}}$ is the extinction coefficient of the free complex.

\section{Fluorescent intercalator displacement (FID) assay}

A 26 base pair self-complementary strand (5'-CAA-TCG-GATCGA-ATT-CGA-TCC-GAT-TG-3') was used (from Eurogentec S.A.). The oligonucleotide was dissolved in Milli $\mathrm{Q}$ water to yield $20 \mu \mathrm{M}$ stock solution. This was then diluted using $10 \mathrm{mM}$ potassium cacodylate $(\mathrm{pH} 7.4) / 50 \mathrm{mM}$ potassium chloride (60 $\mathrm{mM} \mathrm{K}^{+}$) buffer to the appropriate concentrations. Prior to use in the FID assay, the DNA strand was annealed by heating to $95{ }^{\circ} \mathrm{C}$ for $5 \mathrm{~min}$ and then cooled down to room temperature 
overnight. Complex 1, thiazole orange (TO) dye and Hoechst dye were dissolved in DMSO to give $10 \mathrm{mM}$ stock solutions of each. The corresponding solution was then diluted using $10 \mathrm{mM}$ potassium cacodylate $(\mathrm{pH} \quad 7.4) / 50 \mathrm{mM}$ potassium chloride $\left(60 \mathrm{mM} \mathrm{K} \mathrm{K}^{+}\right)$buffer to the appropriate concentrations.

\section{Circular dichroism studies}

Complex 1 was dissolved in DMSO to yield a $10 \mathrm{mM}$ stock solution. This was then diluted using $50 \mathrm{mM}$ Tris- $\mathrm{HCl}(\mathrm{pH}$ 7.4) buffer to the appropriate concentrations. ct-DNA was dissolved directly in $50 \mathrm{mM}$ Tris-HCl (pH 7.4) buffer. The CD spectra were recorded in a strain-free $10 \mathrm{~mm} \times 2 \mathrm{~mm}$ rectangular cell path length cuvette. The data were obtained on an Applied Photophysics Ltd. Chirascan spectrometer. The CD spectra were measured in the wavelength region of $180-700 \mathrm{~nm}$ with the following parameters: bandwidth, $1 \mathrm{~nm}$; spectral range, 230-360 nm; step-size, $0.5 \mathrm{~nm}$; time-pep-point, $1.5 \mathrm{~s}$. The CD spectra were collected and analysed using the Chirascan and Chirascan Viewer software respectively. CD studies were done for ct-DNA with and without varying amounts of 1 (1: base pair $=0.5$ and 1) in Tris-HCl buffer.

\section{Agarose gel electrophoresis}

Plasmid DNA (pUC19) was purchased from Sigma Aldrich. A DNA stock solution of $453 \mu \mathrm{g} \mathrm{mL}{ }^{-1}$ in $10 \mathrm{mM}$ Tris-HCl, pH 8.0, $1 \mathrm{mM}$ EDTA storage buffer was prepared. The DNA binding of 1 was determined by monitoring the conversion of supercoiled plasmid DNA (form I) to nicked circular DNA (form II) and/or linear DNA (form III) using agarose gel electrophoresis. Solutions containing $256 \mathrm{ng}(30 \mu \mathrm{M})$ of DNA and 0, 10, 20, 50,100 and $200 \mu \mathrm{M}$ of 1 with a total reaction volume of $15 \mu \mathrm{L}$ were incubated at $37{ }^{\circ} \mathrm{C}$ for $24 \mathrm{~h}$. After the time period stated, loading buffer (5 $\mu \mathrm{L}$, containing $0.25 \%$ bromophenol blue, $0.25 \%$ xylene cyanol and $60 \%$ glycerol) was added and reaction mixtures were immediately loaded onto $1 \%$ agarose gels containing $1.0 \mu \mathrm{g} \mathrm{mL}^{-1}$ of ethidium bromide. The DNA fragments were separated by applying $40 \mathrm{~V}$ for $1 \mathrm{~h}$ in Tris-acetate EDTA (TAE) buffer. The DNA bands were analysed under UV light using the Fujifilm Image Reader LAS-3000.

\section{Cytotoxicity MTS assay}

Cells $\left(5 \times 10^{4}\right.$ for U2OS, $5 \times 10^{4}$ for HEK $293 \mathrm{~T}, 1 \times 10^{4}$ for GM05757, $5 \times 10^{4}$ for SH-SY5Y, $2 \times 10^{4}$ for NIH 3T3) were seeded in each well of a 96-well plate. After incubating the cells overnight, various concentrations of $1(0.2-500 \mu \mathrm{M})$ were added and incubated for $24 \mathrm{~h}$ (total volume $100 \mu \mathrm{L}$ ). For the mode of death determination assays, the necrosis and autophagocytosis inhibitors, necrostatin-1 (60 $\mu \mathrm{M})$, 3-aminobenzamide $(2 \mathrm{mM})$ or chloroquine $(10 \mu \mathrm{M})$ were added to the cells and incubated for 1 or $6 \mathrm{~h}$ prior to treatment with 1 . The test compound was prepared as a $10 \mathrm{mM}$ solution in DMSO and diluted further using DMSO. The final concentration of DMSO in each well was $4 \%$ (this concentration of DMSO was used at the untreated control). Cisplatin was prepared as a $10 \mathrm{mM}$ solution in PBS: DMSO, $5: 1$ and diluted further using PBS. After the incubation period, $20 \mu \mathrm{L}$ of the MTS solution (made up of $2 \mathrm{mg} \mathrm{mL}^{-1}$
MTS reagent $+100 \mu \mathrm{L}$ of PMS $0.96 \mathrm{mg} \mathrm{mL}^{-1}$ ) was added to each well. The mixture was incubated for a further $1.5-4 \mathrm{~h}$ at $37{ }^{\circ} \mathrm{C}$. After this time, an ELISA reader was used to record the absorption at $490 \mathrm{~nm}$ and the $\mathrm{IC}_{50}$ values were determined using the conventional method. $\mathrm{IC}_{50}$ values were calculated from the following equation: $\mathrm{Abs} \mathrm{IC}_{50}=\left(\mathrm{Abs} \mathrm{IC}_{0}+\mathrm{Abs} \mathrm{IC}_{100}\right) / 2$, where $\mathrm{IC}_{0}$ is the mean absorption at $490 \mathrm{~nm}$ of the media only and $\mathrm{IC}_{100}$ is the mean absorption at $490 \mathrm{~nm}$ of the cells only. Then the $X$-axis intercept of the dose-response curve at Abs $\mathrm{IC}_{50}$ (determined by the above equation) was considered as the $\mathrm{IC}_{50}$ value for each test compound. The dose-response curve is a plot of absorption at $490 \mathrm{~nm}$ ( $y$-axis) and the concentration of test compound exposed to the cells ( $x$-axis). Prior to plotting the curve the background absorption (due to the reaction of the test compound and MTS reagents) was subtracted from the absorption values obtained from the cells that had been incubated with the compounds.

\section{Cellular uptake studies}

To measure the cellular uptake of $\mathbf{1}, c a .2$ million U2OS, HEK 293T, GM05757, SH-SY5Y and NIH 3T3 (proliferating and nonproliferating conditions) cells were treated with $10 \mu \mathrm{M}$ of the complex at $37{ }^{\circ} \mathrm{C}$ for $24 \mathrm{~h}$. Then the media were removed, the cells were washed with PBS solution $(\times 3)$, harvested and centrifuged. The cellular pellet was suspended in an appropriate volume of PBS to obtain a homogeneous cell suspension. The suspension was divided in two. One part was used to analyse the metal content in the whole cell and the other was used for the cytoplasmic and nucleus analysis. The Thermo Scientific NE-PER Nuclear and Cytoplasmic Extraction Kit was used to extract the separate cytoplasmic and nuclear fractions. From each of the fractions, aliquots were removed for protein determination using the Bradford assay (carried out according to the instructions of the manufacturer: Sigma Aldrich, microwell plate protocol). The remaining cell suspension was mineralized with $65 \% \mathrm{HNO}_{3}$ and then completely dried at $120{ }^{\circ} \mathrm{C}$. The solid extracts were re-dissolved in $2 \% \mathrm{HNO}_{3}$ and analysed using ICP-MS. Cellular metal levels were expressed as ng Pt per mg protein. Results are presented as the mean of 4 or 5 determinations for each data point. The fraction of the administered complexes that were taken up by the cells was calculated by dividing the amount of complex detected in the whole cell, cytoplasm and nucleus (i.e. the raw measurement in ng) by the total mass of metal corresponding to the concentration administered for each complex (10 $\mathrm{M}$ converted to ng). The fractions were normalised so that all treated cells were accounted. The percentage of the administered complexes that were taken up by the cells was then determined by multiplying the normalised fractions by 100 .

\section{Flow cytometry studies}

In order to monitor the cell cycle, flow cytometry studies were carried out. U2OS cells were incubated with and without $10 \mu \mathrm{M}$ 1 for $24 \mathrm{~h}$ at $37^{\circ} \mathrm{C}$. Studies on NIH 3T3 cells under normal and starved (proliferating and non-proliferating) conditions were also carried out. Cells were harvested from adherent cultures by 
trypsinization and combined with all detached cells from the incubation medium to assess the total cell viability. Following centrifugation at $1000 \mathrm{rpm}$ for $5 \mathrm{~min}$, cells were washed with PBS and then fixed with $70 \%$ ethanol in PBS. Fixed cells were collected by centrifugation at $2500 \mathrm{rpm}$ for $3 \mathrm{~min}$, washed with PBS and centrifuged as before. Cellular pellets were re-suspended in $50 \mu \mathrm{g} \mathrm{mL}^{-1}$ propidium iodide (Calbiochem) in PBS for nucleic acids staining and treated with $100 \mu \mathrm{g} \mathrm{mL}^{-1}$ RNaseA (Sigma). DNA content was measured on a FACSCalibur flow cytometer (BD Biosciences) using laser excitation at $488 \mathrm{~nm}$ and 10000 events per sample were acquired. Cell cycle profiles were analysed using the FlowJo software (Tree Star). For the annexin V experiments, the Invitrogen FITC Annexin V/Dead Cell Apoptosis Kit was used. The manufacturer's protocol was followed to carry out this experiment. Briefly, untreated and treated cells $\left(1 \times 10^{5}\right)$ were suspended in binding buffer (10 mM HEPES, $140 \mathrm{mM} \mathrm{NaCl}$, $2.5 \mathrm{mM} \mathrm{CaCl}_{2}, \mathrm{pH} 7.4$ ), then $5 \mu \mathrm{L}$ FITC annexin $\mathrm{V}$ and $1 \mu \mathrm{L} \mathrm{PI}$ $\left(100 \mu \mathrm{g} \mathrm{mL}{ }^{-1}\right)$ were added to each sample and incubated at room temperature for $15 \mathrm{~min}$., after which more binding buffer $(400 \mu \mathrm{L})$ was added while mixing gently. The samples were kept on ice prior to being read on the FACSCalibur flow cytometer (BD Biosciences) using laser excitation at $488 \mathrm{~nm}$ (10 000 events per sample were acquired). Cell cycle profiles were analysed using the FlowJo software (Tree Star).

\section{Immunoblot analysis}

For protein analysis by immunoblotting, U2OS cells $(5 \times$ $10^{5}$ cells) were incubated with the indicated concentrations of 1 for $24 \mathrm{~h}$ at $37{ }^{\circ} \mathrm{C}$. Cells were washed with PBS, scraped into SDS-PAGE loading buffer (64 mM Tris-HCl (pH 6.8)/9.6\% glycerol $/ 2 \%$ SDS/5\% $\beta$-mercaptoethanol/0.01\% bromophenol blue) and incubated at $95{ }^{\circ} \mathrm{C}$ for $10 \mathrm{~min}$. Whole cell lysates were resolved by $12 \%$ sodium dodecylsulphate polyacrylamide gel electrophoresis (SDS-PAGE; $200 \mathrm{~V}$ for $1 \mathrm{~h}$ ), followed by electron transfer to nitrocellulose membrane $(400 \mathrm{~mA}$ for $1 \mathrm{~h})$. Membranes were blocked in 5\% (w/v) non-fat milk in PBST (PBS/0.1\% Tween 20) and incubated with one of the following primary antibodies: anti-p53 (DO-1, Santa Cruz), anti-p21 (C-19, Santa Cruz), anti-Chk2 (2662, Cell Signalling Technology), anti-phospho-Chk2 (2661, Cell Signalling Technology), antiBAX (P-19, Santa Cruz), anti-caspase-3 (E-8, Santa Cruz), anticyclin D1 (A-12, Santa Cruz), anti-phospho-Histone H2A.X (2577, Cell Signalling Technology) and anti- $\alpha$-tubulin (TAT-1, Cancer Research UK). After incubation with horseradish peroxidaseconjugated secondary antibodies, immune complexes were detected with the ECL detection reagent (Millipore) and analysed using the Fujifilm Image Reader LAS-3000.

\section{Extraction of HMGB1 released into culture media}

U2OS cells $\left(1 \times 10^{6}\right.$ cells $)$ were incubated with $1(50-200 \mu \mathrm{M})$ for $48 \mathrm{~h}$ at $37^{\circ} \mathrm{C}$ to induce cell death. As a positive control, necrosis was induced by heating cells at $56{ }^{\circ} \mathrm{C}$ for $30 \mathrm{~min}$, followed by incubation at $37^{\circ} \mathrm{C}$ for an additional $1 \mathrm{~h}$. The protein contained within the culture media was precipitated. Protein precipitation was carried out by adding methanol $(4 \times$ volume), chloroform $(1 \times)$ and $\mathrm{ddH}_{2} \mathrm{O}(3 \times)$, vortexing and then centrifugation at
$5000 \mathrm{rpm}$ for $2 \mathrm{~min}$. The aqueous layer was removed and more methanol $(4 \times$ volume $)$ was added. Following mixing and centrifugation as before, the methanol was removed. The resultant protein precipitate was air dried, dissolved in SDSPAGE loading buffer (64 mM Tris- $\mathrm{HCl}$ (pH 6.8)/9.6\% glycerol/ $2 \%$ SDS/5\% $\beta$-mercaptoethanol/0.01\% bromophenol blue) and incubated at $95{ }^{\circ} \mathrm{C}$ for $10 \mathrm{~min}$. The HMGB1 content was probed by immunoblotting analysis as described above. The antiHMGB1 anti-body (3935, Cell Signalling Technology) was used in this experiment.

\section{Acknowledgements}

The UK's Engineering and Physical Sciences Research Council (EPSRC) is thanked for funding (grant number: EP/H005285/1) and Johnsons Matthey for a loan of platinum.

\section{References}

1 Z. Guo and P. J. Sadler, Angew. Chem., Int. Ed., 1999, 38, 1512-1531.

2 T. W. Hambley, Science, 2007, 318, 1392-1393.

3 B. K. Keppler, Metal complexes in cancer chemotherapy, $\mathrm{VCH}$, Weinheim, New York, 1993.

4 I. Kostova, Recent Pat. Anti-cancer Drug Discovery, 2006, 1, $1-22$.

$5 \mathrm{H}$. Sigel and A. Sigel, Metal complexes as anticancer agents, M. Dekker, New York, 1980.

6 C. X. Zhang and S. J. Lippard, Curr. Opin. Chem. Biol., 2003, 7, 481-489.

7 P. J. Dyson and G. Sava, Dalton Trans., 2006, 1929-1933.

8 P. Carloni, M. Sprik and W. Andreoni, J. Phys. Chem. B, 2000, 104, 823-835.

9 H. C. Harder and B. Rosenberg, Int. J. Cancer, 1970, 6, 207-216.

10 J. A. Howle and G. R. Gale, Biochem. Pharmacol., 1970, 19, 2757-2762.

11 E. R. Jamieson and S. J. Lippard, Chem. Rev., 1999, 99, 2467-2498.

12 S. E. Sherman and S. J. Lippard, Chem. Rev., 1987, 87, 1153-1181.

13 D. Tullius Thomas, M. H. Ushay, M. M. Carolyn, P. C. John and J. L. Stephen, Platinum, Gold, and Other Metal Chemotherapeutic Agents, ACS, 1983, vol. 209, pp. 51-74.

14 S. M. Cohen and S. J. Lippard, Prog. Nucleic Acid Res. Mol. Biol., 2001, 67, 93-130.

15 Y. Jung and S. J. Lippard, J. Biol. Chem., 2006, 281, 1361-1370.

16 M. A. Fuertes, C. Alonso and J. M. Perez, Chem. Rev., 2003, 103, 645-662.

17 M. Galanski, M. A. Jakupec and B. K. Keppler, Curr. Med. Chem., 2005, 12, 2075-2094.

18 J. K. Barton and S. J. Lippard, Biochemistry, 1979, 18, 2661-2668.

19 A. Odani, R. Shimata, H. Masuda and O. Yamauchi, Inorg. Chem., 1991, 30, 2133-2138. 
20 B. M. Zeglis, V. C. Pierre and J. K. Barton, Chem. Commun., 2007, 4565-4579.

21 D. M. Fisher, R. R. Fenton and J. R. Aldrich-Wright, Chem. Commun., 2008, 5613-5615.

22 P. J. Bond, R. Langridge, K. W. Jennette and S. J. Lippard, Proc. Natl. Acad. Sci. U. S. A., 1975, 72, 4825-4829.

23 Z. D. Bugarcic, F. W. Heinemann and R. v. Eldik, Dalton Trans., 2004, 279-286.

24 S. J. Lippard, Acc. Chem. Res., 1978, 11, 211-217.

25 G. Lowe, J. A. McCloskey, J. Ni and T. Vilaivan, Bioorg. Med. Chem., 1996, 4, 1007-1013.

26 G. Lowe and T. Vilaivan, J. Chem. Soc., Perkin Trans. 1, 1996, 1499-1503.

27 D. Petrović, B. Stojimirović, B. Petrović, Z. M. Bugarčić and Ž. D. Bugarčić, Bioorg. Med. Chem., 2007, 15, 4203-4211.

28 K. G. Strothkamp and S. J. Lippard, Proc. Natl. Acad. Sci. U. S. A., 1976, 73, 2536-2540.

29 S. D. Cummings, Coord. Chem. Rev., 2009, 253, 1495-1516.

30 W. D. McFadyen, L. P. Wakelin, I. A. Roos and V. A. Leopold, J. Med. Chem., 1985, 28, 1113-1116.

31 W. D. McFadyen, L. P. Wakelin, I. A. Roos and B. L. Hillcoat, Biochem. J., 1986, 238, 757-763.

32 E. L. Crossley, D. Caiazza and L. M. Rendina, Dalton Trans., 2005, 2825-2826.

33 G. Lowe, A. S. Droz, T. Vilaivan, G. W. Weaver, J. J. Park, J. M. Pratt, L. Tweedale and L. R. Kelland, J. Med. Chem., 1999, 42, 3167-3174.

34 D.-L. Ma, T. Y.-T. Shum, F. Zhang, C.-M. Che and M. Yang, Chem. Commun., 2005, 4675-4677.

35 J. A. Todd and L. M. Rendina, Inorg. Chem., 2002, 41, 3331-3333.

36 J. A. Todd, P. Turner, E. J. Ziolkowski and L. M. Rendina, Inorg. Chem., 2005, 44, 6401-6408.

37 S. L. Woodhouse, E. J. Ziolkowski and L. M. Rendina, Dalton Trans., 2005, 2827-2829.

38 G. Arena, L. M. Scolaro, R. F. Pasternack and R. Romeo, Inorg. Chem., 1995, 34, 2994-3002.

39 C. Sessa, O. Pagani, M. G. Zurlo, J. de Jong, C. Hofmann, M. Lassus, P. Marrari, M. S. Benedetti and F. Cavalli, Ann. Oncol., 1994, 5, 901-907.

40 J. Viallet, D. Stewart, F. Shepherd, J. Ayoub, Y. Cormier, N. DiPietro and W. Steward, J. Lung Cancer, 1996, 15, 367-373.

41 F. Caponigro, D. Lorusso, G. Fornari, C. Barone, M. Merlano, M. Airoldi, M. Schena, R. MacArthur, S. Weitman, M. G. Jannuzzo, S. Crippa, F. Fiorentini, A. Petroccione and S. Comis, Cancer Chemother. Pharmacol., 2010, 66, 389-394.

42 A. J. ten Tije, J. Verweij, A. Sparreboom, A. van der Gaast, C. Fowst, F. Fiorentini, J. Tursi, A. Antonellini, M. Mantel, C. M. Hartman, G. Stoter, A. S. T. Planting and M. J. A. de Jonge, Clin. Cancer Res., 2003, 9, 2957-2964.

43 M. Howe-Grant, K. C. Wu, W. R. Bauer and S. J. Lippard, Biochemistry, 1976, 15, 4339-4346.

44 W. D. McFadyen, L. P. Wakelin, I. A. Roos and B. L. Hillcoat, Biochem. J., 1987, 242, 177-183.
45 L. Messori, G. Marcon, A. Innocenti, E. Gallori, M. Franchi and P. Orioli, Bioinorg. Chem. Appl., 2005, 239-253.

46 R. Kieltyka, J. Fakhoury, N. Moitessier and H. F. Sleiman, Chem.-Eur. J., 2008, 14, 1145-1154.

47 C. Rajput, R. Rutkaite, L. Swanson, I. Haq and J. A. Thomas, Chem.-Eur. J., 2006, 12, 4611-4619.

48 E. Largy, F. Hamon and M. P. Teulade-Fichou, Anal. Bioanal. Chem., 2011, 400, 3419-3427.

49 D. Monchaud, C. Allain, H. Bertrand, N. Smargiasso, F. Rosu, V. Gabelica, A. De Cian, J. L. Mergny and M. P. Teulade-Fichou, Biochimie, 2008, 90, 1207-1223.

50 D. Monchaud, C. Allain and M. P. Teulade-Fichou, Nucleosides, Nucleotides Nucleic Acids, 2007, 26, 1585-1588.

51 D. Monchaud and M. P. Teulade-Fichou, Methods Mol. Cell. Biol., 2010, 608, 257-271.

52 P. U. Maheswari, S. Roy, H. den Dulk, S. Barends, G. van Wezel, B. Kozlevcǎr, P. Gamez and J. Reedijk, J. Am. Chem. Soc., 2005, 128, 710-711.

53 B. Selvakumar, V. Rajendiran, P. Uma Maheswari, H. Stoeckli-Evans and M. Palaniandavar, J. Inorg. Biochem., 2006, 100, 316-330.

54 P. X. Xi, Z. H. Xu, X. H. Liu, F. J. Chen, Z. Z. Zeng, X. W. Zhang and Y. Liu, J. Fluoresc., 2009, 19, 63-72.

55 G. M. Morris, D. S. Goodsell, R. S. Halliday, R. Huey, W. E. Hart, R. K. Belew and A. J. Olson, J. Comput. Chem., 1998, 19, 1639-1662.

56 J. K. Barton and E. Lolis, J. Am. Chem. Soc., 1985, 107, 708-709.

57 S. L. H. Higgins, A. J. Tucker, B. S. J. Winkel and K. J. Brewer, Chem. Commun., 2012, 48, 67-69.

58 R. L. Williams, H. N. Toft, B. Winkel and K. J. Brewer, Inorg. Chem., 2003, 42, 4394-4400.

59 K. Suntharalingam, A. J. P. White and R. Vilar, Inorg. Chem., 2009, 48, 9427-9435.

60 K. Suntharalingam, D. J. Hunt, A. A. Duarte, A. J. P. White, D. J. Mann and R. Vilar, Chem.-Eur. J., 2012, 18, 15133-15141.

61 T. Boulikas and M. Vougiouka, Oncol. Rep., 2003, 10, 1663-1682. 62 J. Y. Ahn, J. K. Schwarz, H. Piwnica-Worms and C. E. Canman, Cancer Res., 2000, 60, 5934-5936.

63 S. Burma, B. P. Chen, M. Murphy, A. Kurimasa and D. J. Chen, J. Biol. Chem., 2001, 276, 42462-42467.

64 S. Matsuoka, G. Rotman, A. Ogawa, Y. Shiloh, K. Tamai and S. J. Elledge, Proc. Natl. Acad. Sci. U. S. A., 2000, 97, 10389-10394.

65 R. Melchionna, X.-B. Chen, A. Blasina and C. H. McGowan, Nat. Cell Biol., 2000, 2, 762-765.

66 E. P. Rogakou, D. R. Pilch, A. H. Orr, V. S. Ivanova and W. M. Bonner, J. Biol. Chem., 1998, 273, 5858-5868.

67 T. M. Gottlieb and M. Oren, Semin. Cancer Biol., 1998, 8, 359-368.

68 L. H. Hartwell and M. B. Kastan, Science, 1994, 266, 1821-1828.

69 L. Gatti, R. Supino, P. Perego, R. Pavesi, C. Caserini, N. Carenini, S. C. Righetti, V. Zuco and F. Zunino, Cell Death Differ., 2002, 9, 1352-1359. 
70 D. P. Lane, Nature, 1992, 358, 15-16.

71 B. Vogelstein, D. Lane and A. J. Levine, Nature, 2000, 408, 307-310.

72 H. Matsushime, M. E. Ewen, D. K. Strom, J. Y. Kato, S. K. Hanks, M. F. Roussel and C. J. Sherr, Cell, 1992, 71, 323-334.

73 H. Matsushime, D. E. Quelle, S. A. Shurtleff, M. Shibuya, C. J. Sherr and J. Y. Kato, Mol. Cell. Biol., 1994, 14, 2066-2076.

74 S. W. Tam, A. M. Theodoras, J. W. Shay, G. F. Draetta and M. Pagano, Oncogene, 1994, 9, 2663-2674.

75 Z. D. Lan, Z. Sever-Chroneos, M. W. Strobeck, C. H. Park, R. Baskaran, W. Edelmann, G. Leone and E. S. Knudsen, J. Biol. Chem., 2002, 277, 8372-8381.

76 L. L. Pontano and J. A. Diehl, Cell Cycle, 2009, 8, 824-827.

77 M. K. Santra, N. Wajapeyee and M. R. Green, Nature, 2009, 459, 722-725.

78 N. Suwaki, E. S. Child, L. M. Elphick and D. J. Mann, Arch. Biochem. Biophys., 2010, 497, 55-61.

79 J. F. Kerr, A. H. Wyllie and A. R. Currie, Br. J. Cancer, 1972, 26, 239-257.

80 J. F. R. Kerr, J. Pathol. Bacteriol., 1965, 90, 419-435.

81 S. Kasibhatla, T. Brunner, L. Genestier, F. Echeverri, A. Mahboubi and D. R. Green, Mol. Cell, 1998, 1, 543-551.

82 M. MacFarlane, N. A. Jones, C. Dive and G. M. Cohen, Mol. Pharmacol., 1996, 50, 900-911.
83 Y. Sedletska, M. J. Giraud-Panis and J. M. Malinge, Curr. Med. Chem.: Anti-cancer Agents, 2005, 5, 251-265.

84 E. P. Simoes Magluta, F. C. Vasconcelos, R. C. Maia and C. E. Klumb, Cancer Invest., 2009, 27, 830-835.

85 J. Pan, C. Cheng, S. Verstovsek, Q. Chen, Y. Jin and Q. Cao, Cancer Lett., 2010, 293, 167-174.

86 P. Scaffidi, Nature, 2002, 418, 191.

87 A. Agresti, Curr. Opin. Genet. Dev., 2003, 13, 170.

88 A. Raucci, R. Palumbo and M. E. Bianchi, Autoimmunity, 2007, 40, 285-289.

89 R. J. Ernst, A. C. Komor and J. K. Barton, Biochemistry, 2011, 50, 10919-10928.

90 J. Hitomi, D. E. Christofferson, A. Ng, J. Yao, A. Degterev, R. J. Xavier and J. Yuan, Cell, 2008, 135, 1311-1323.

91 F. K. Chan, J. Shisler, J. G. Bixby, M. Felices, L. Zheng, M. Appel, J. Orenstein, B. Moss and M. J. Lenardo, J. Biol. Chem., 2003, 278, 51613-51621.

92 A. L. Edinger and C. B. Thompson, Curr. Opin. Cell Biol., 2004, 16, 663-669.

93 L. Galluzzi and G. Kroemer, Cell, 2008, 135, 1161-1163.

94 G. Kroemer, W. S. El-Deiry, P. Golstein, M. E. Peter, D. Vaux, P. Vandenabeele, B. Zhivotovsky, M. V. Blagosklonny, W. Malorni, R. A. Knight, M. Piacentini, S. Nagata and G. Melino, Cell Death Differ., 2005, 12(suppl 2), 1463-1467. 95 M. S. Ricci and W. X. Zong, Oncologist, 2006, 11, 342-357. 